\title{
Status of coral reefs of Upolu (Independent State of Samoa) in the South West Pacific and recommendations to promote resilience and recovery of coastal ecosystems
}

\author{
Maren Ziegler $^{\mathrm{a}, *}$, Gaëlle Quérée,c, Jean-François Ghiglione ${ }^{\mathrm{d}}$, Guillaume Iwankow $^{\mathrm{b}, \mathrm{c}}$, \\ Valérie Barbe $^{\mathrm{e}}$, Emilie Boissin ${ }^{\mathrm{b}, \mathrm{c}}$, Patrick Wincker ${ }^{\mathrm{e}, \mathrm{f}, \mathrm{g}}$, Serge Planes ${ }^{\mathrm{b}, \mathrm{c}}$, Christian R. Voolstra ${ }^{\mathrm{a}}$ \\ a Red Sea Research Center, Division of Biological and Environmental Science and Engineering (BESE), 4700 King Abdullah University of Science and Technology (KAUST), \\ 23955-6900 Thuwal, Saudi Arabia \\ ${ }^{\mathrm{b}}$ EPHE, PSL Research University, UPVD, CNRS, USR 3278 CRIOBE, BP 1013, 98729 Papetoai, Moorea, French Polynesia \\ ${ }^{c}$ Laboratoire d'Excellence 'CORAIL', Papetoai, Moorea, French Polynesia \\ ${ }^{\mathrm{d}}$ UPMC Univ Paris 06, CNRS, Laboratoire d'Océanographie Microbienne (LOMIC), Observatoire Océanologique, Sorbonne Universités, 66650 Banyuls/mer, France \\ e Commissariat à l'Energie Atomique et aux Energies Alternatives, Genoscope, Institut de biologie François-Jacob, 2 Rue Gaston Crémieux, 91000 Evry, France \\ ${ }^{\mathrm{f}}$ CNRS UMR 8030, Evry, France \\ ${ }^{g}$ Univ. Evry, Univ. Paris-Saclay, Evry, France
}

\section{A R T I C L E I N F O}

\section{Keywords:}

Monitoring

Coral reef degradation

Climate change

Marine resource management

\begin{abstract}
A B S T R A C T
Coral reef ecosystems worldwide are immediately threatened by the impacts of climate change. Here we report on the condition of coral reefs over $83 \mathrm{~km}$ of coastline at the island of Upolu, Samoa in the remote South West Pacific in 2016 during the Tara Pacific Expedition. Despite the distance to large urban centers, coral cover was extremely low $(<1 \%)$ at approximately half of the sites and below $10 \%$ at $78 \%$ of sites. Two reef fish species, Acanthurus triostegus and Zanclus cornutus, were 10\% smaller at Upolu than at neighboring islands. Importantly, coral cover was higher within marine protected areas, indicating that local management action remains a useful tool to support the resilience of local reef ecosystems to anthropogenic impacts. This study may be interpreted as cautionary sign for reef ecosystem health in remote locations on this planet, reinforcing the need to immediately reduce anthropogenic impacts on a global scale.
\end{abstract}

\section{Introduction}

Coral reefs are immediately threatened by the impacts of global climate change (Hoegh-Guldberg et al., 2007). Projected increases in severity of tropical storms will probably physically devastate coral reef ecosystems (Webster et al., 2005). In addition global warming and increasing seawater temperatures are the main cause for coral bleaching, which is the disruption of the symbiosis between the coral animal and its endosymbiotic algae (Hoegh-Guldberg et al., 2007; Hughes et al., 2003). Coral bleaching can lead to the mortality of the coral host and the degradation of entire coral reef ecosystems (Graham et al., 2006). The El Niño Year 2015/2016 was declared as the "Third Global Coral Bleaching Event" and hot seawater temperatures in 2017 caused widespread coral bleaching during three consecutive years.

Much data has been collected on the status of well-known reef areas, such as the Great Barrier Reef that has been heavily impacted by climate change (De'ath et al., 2012; Hughes et al., 2017). The status of coral reefs in more remote locations, such as the small island states in the Pacific, is less well understood and regular monitoring data on reef health from these locations is often wanting. At the same time, small island populations largely rely on intact coral reef ecosystems, as they directly live from coral reef fisheries, tourism, and coastal protection.

The Tara Pacific Expedition visited the island of Upolu, Independent State of Samoa in the South West Pacific from Nov. 29 to Dec. 03, 2016 to conduct a sampling campaign of hard corals, fish, and coral reef water. Given the extent of the damage observed on the reefs, it was decided to complete a comprehensive survey of Upolu's reef health. During this time, $83 \mathrm{~km}$ of coastal coral reefs were surveyed, the results of which are reported herein.

\footnotetext{
* Corresponding author at: 4700 King Abdullah University of Science and Technology (KAUST), Building 2, Office 2227, 3955-6900 Thuwal, Saudi Arabia.

E-mail address: Maren.Ziegler@kaust.edu.sa (M. Ziegler).
} 


\section{Materials and methods}

\subsection{Literature review of disturbance history}

Scientific literature and reports ("grey literature") provided by the Samoa Ministry of Natural Resources and Environment were searched for information on the disturbance history of coral reef ecosystems at Upolu with a focus on storm damage, outbreaks of coral-eating crownof-thorns starfish (COTS), unsustainable use of resources, land-based pollution, and coral bleaching.

\subsection{Fish sampling}

As part of the Tara Pacific Expedition, two species of reef fish, Acanthurus triostegus and Zanclus cornutus, were sampled at three sites per island. For this study, we report total lengths of the fish caught at Upolu and compare them to the lengths of the fish caught at three islands that were previously visited during the expedition: Moorea (French Polynesia), Aitutaki (Cook Islands, NZ), and Niue (NZ). Furthermore, behavioral observations of the two species from Upolu are reported.

\subsection{Survey area and methods}

Coral reef surveys were conducted at 124 sites over $83 \mathrm{~km}$ of coastline at the Samoan main island of Upolu between Nov. 29 and Dec. 03, 2016 (Fig. 1). These sites were distributed on fore reef locations of the west, southwest to central south (89 sites, reef area covered during surveys: $57 \mathrm{~km}$ ), east (18 sites, $14 \mathrm{~km}$ ), and north east (17 sites, $12 \mathrm{~km}$ ) coast of Upolu in areas expected to feature rich coral reef ecosystems based on satellite imagery and literature searches.

Quick assessments of substrate cover at shallow survey points located between 1 and $11 \mathrm{~m}$ water depth were conducted from a small vessel on snorkel by two independent observers with previous experience at substrate surveys (Jokiel et al., 2015). Not every survey point included the full depth range, depending on the slope at the site.
Substrate cover at each GPS point was estimated to the nearest $5 \%$ in the following categories: percent cover of hard corals (CO), turf algae (TA), macro algae (MA), crustose coralline algae (CCA), and non-colonized substrate such as sand and rock (other).

\section{Results \& discussion}

\subsection{Disturbance history of Upolu}

Upolu has repeatedly been hit by tropical cyclones that devastated the livelihood of the island's inhabitants and caused physical damage to coral reef ecosystems. In 1990 cyclone Ofa and 18 months later cyclone Val heavily affected coral reefs on Upolu's north coast and some areas on the west and southwest coast while the east and south coast remained largely unaffected (Zann and Bell, 1991). In 2004, cyclone Heta hit reefs in the central Pacific and likely also Upolu, but its effect on the local coral reefs is largely undocumented. In 2009 a tsunami hit Upolu's shores from the opposite direction than the previous cyclones. In areas of the southeast and east of the island that were affected by the tsunami, no decreases in live coral cover, but an increase in macro algae shortly after the tsunami was recorded (possibly related to the mobilization of nutrients) (McAdoo et al., 2011). In 2012, cyclone Evan affected areas along the south and north coast of Upolu and, in addition to windcaused damage, heavy rainfall caused flooding and run-off of sediments and nutrients into coastal ecosystems (Government of Samoa, 2013).

Local stressors, such as pollution, eutrophication, and overfishing may exacerbate the negative impacts of climate change on coral reef ecosystems (Fabricius, 2005; Zaneveld et al., 2016). Unsustainable use of natural resources and destructive fishing practices such as dynamite and poison fishing have been reported from Samoa as early as 1989 (Bell, 1989). This can lead to the physical destruction of coral reef habitat, and overfishing and poison fishing also favor degradation of coral-dominated ecosystems to ecosystems dominated by macro algae, sponges, or soft corals that do not support the same ecosystem services as hard coral-dominated reefs. Overfishing disturbs the reef fish community that helps to keep a balance on coral reefs by selectively

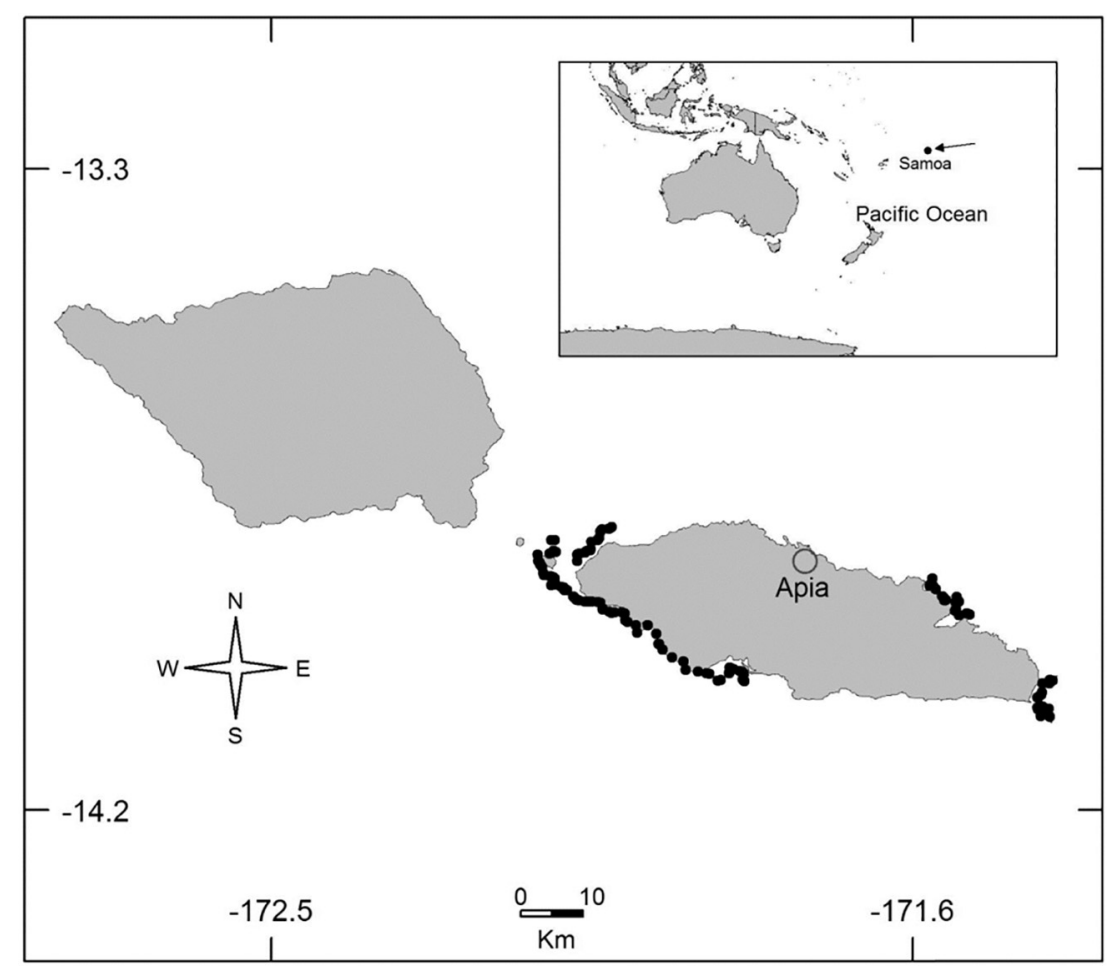

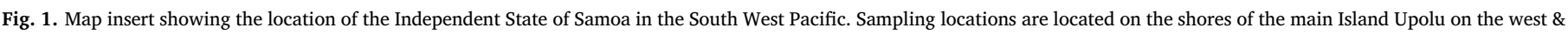
south and the east \& north east coast (denoted with black circles). 


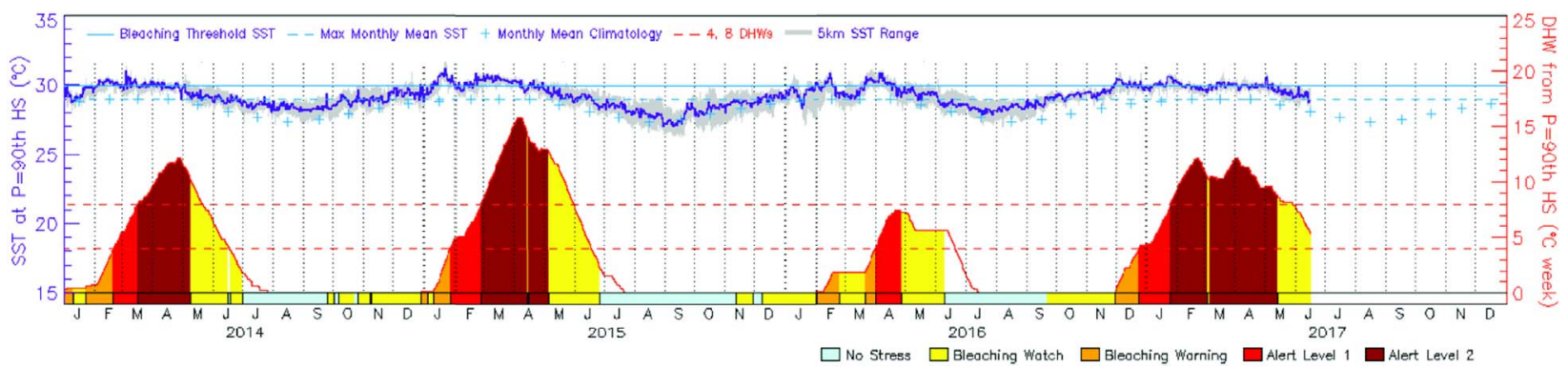

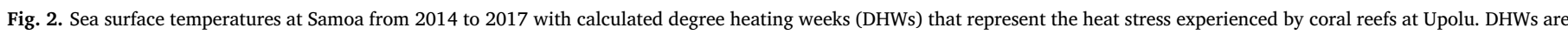

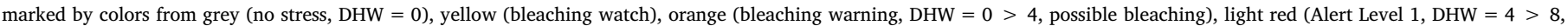

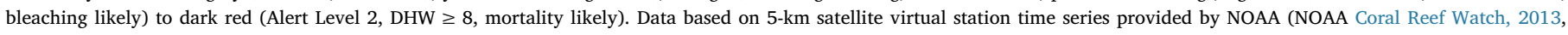

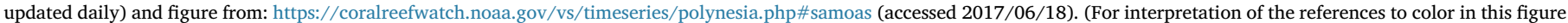
legend, the reader is referred to the web version of this article.)

\section{a) Acanthurus triostegus}

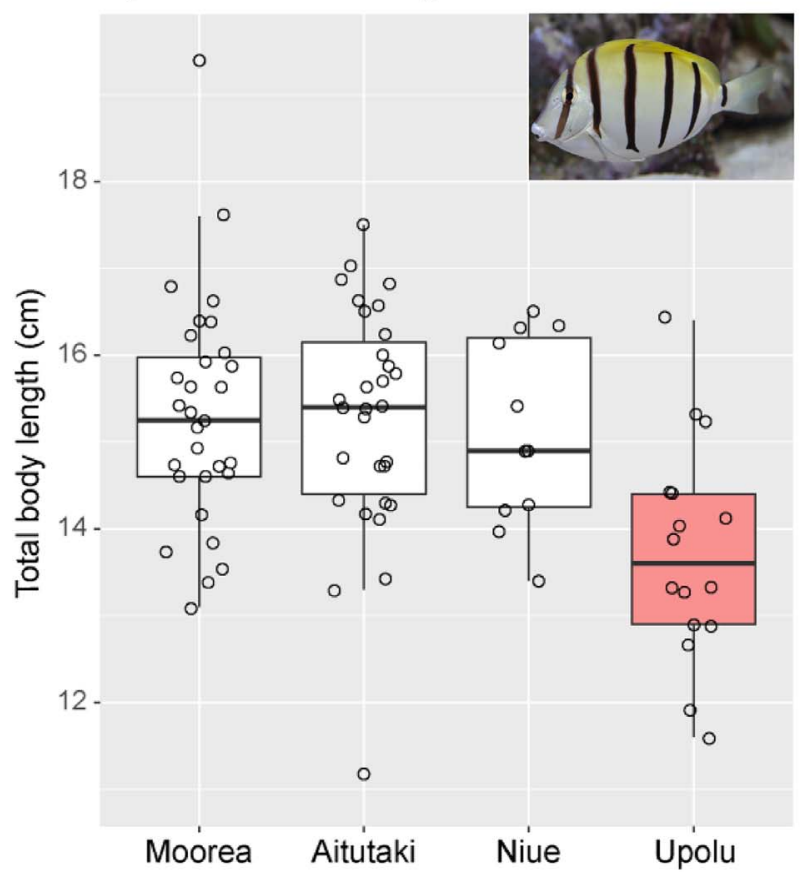

b) Zanclus cornutus

$18-$
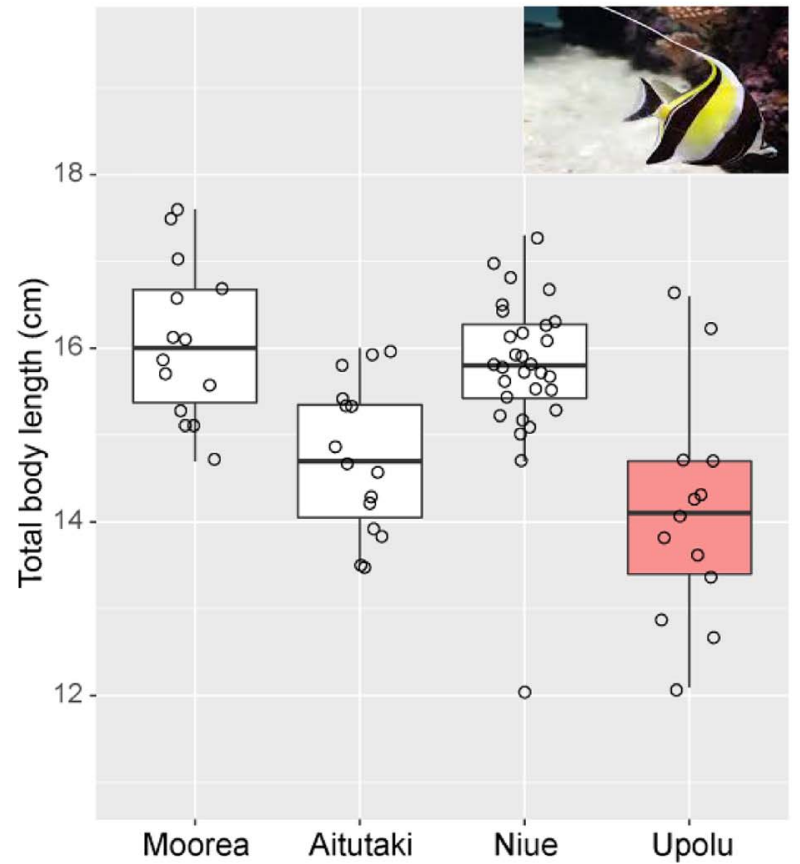

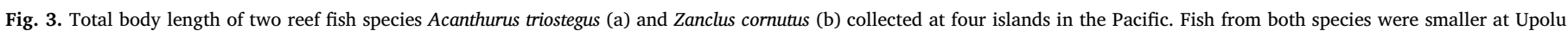

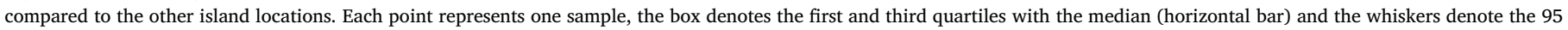
percentiles.

removing fast-growing turf and macro algae that compete for space with slow-growing corals (Hughes et al., 2007). Moreover, poison fishing can also directly impact and kill coral colonies (Jones and Steven, 1997).

Outbreaks of coral-eating crown-of-thorns starfish (COTS, Acanthaster spp.) have been observed repeatedly on Upolu's shores, with outbreak episodes in 1969 and 1977-1986 (Zann and Bell, 1991). The most recent outbreak started in 2011 and continued until at least 2015. It has negatively impacted coral cover in affected areas (Kwan et al., 2016), despite collection efforts to mitigate the outbreak (Kwan et al., 2016; Tiitii, 2011).

COTS outbreaks can be caused by increased nutrients in coastal ecosystems, for example after heavy rainfalls, when terrestrial nutrient discharge is increased (Brodie et al., 2005). They are further fostered by a lack of natural predators such as large fish and Triton snails, which are targeted in local fisheries (Cowan et al., 2017). When mitigation strategies to COTS outbreaks were compared in a modeling study, predation of invertebrates on juvenile COTS was more effective than for example manual removal (Morello et al., 2014). At Upolu, manual removal of adult COTS is the main practice to mitigate COTS outbreaks
(Kwan et al., 2016; Tiitii, 2011).

We did not find data that reported on coral bleaching at Upolu. However, it is likely that coral reefs at Upolu were affected by the third global coral bleaching like many other reefs in the Pacific. Based on remotely sensed sea surface temperatures (SST), coral reefs in Samoa experienced three severe thermal anomalies of up to 16 degree heating weeks (DHW) between 2014 and 2017 (Fig. 2), making widespread coral bleaching likely (Liu et al., 2003; Liu et al., 2005). Coral bleaching does not necessarily lead to coral mortality and corals can recover from bleaching depending on the severity of the thermal anomaly and if other stressors are kept at a minimum. Because of the severity of the observed thermal anomalies at Upolu, both in terms of the high temperatures reached and the duration of the anomaly that resulted in bleaching alert level 2 for several weeks, coral mortality was likely.

\subsection{Small, shy fish}

Acanthurus triostegus and Zanclus cornutus were about $10 \%$ smaller at Upolu when compared to conspecifics caught off the islands of Moorea (French Polynesia), Aitutaki (Cook Islands), and Niue (Fig. 3). 


\section{a) West \& south coast}

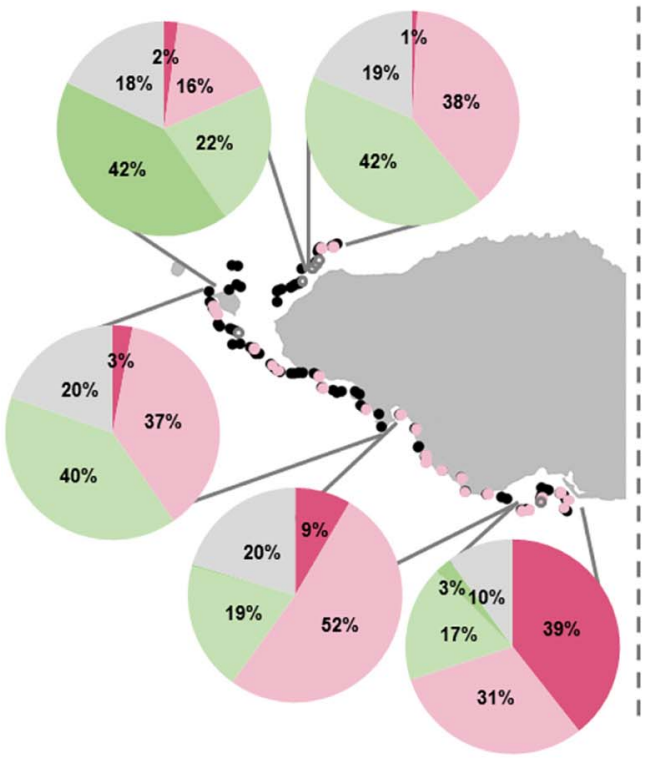

\section{b) East \& north-eastern coast}

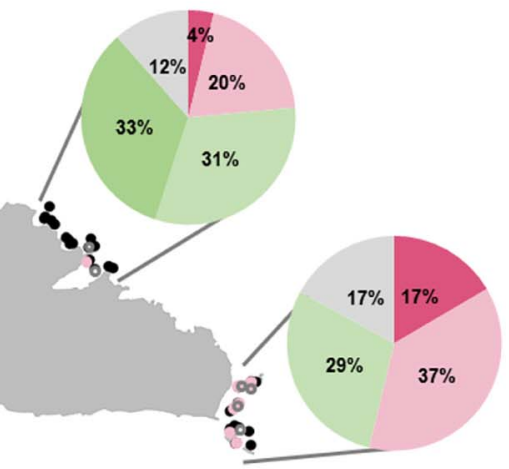

\begin{tabular}{|l|}
\hline Substrate key \\
coral coralline algae \\
turf algae macro algae \\
other (rock/sand)
\end{tabular}

Fig. 4. Summary of substrate cover at shallow survey points between 1 and $11 \mathrm{~m}$ water depth on reef slopes along the west \& south coast (a) and the east \& north east coast (b) of the island of Upolu. Survey points are colour coded if site had high coralline algae cover (filled pink circle), many coral recruits (grey circle), or both (grey circles filled pink). (For interpretation of the references to color in this figure legend, the reader is referred to the web version of this article.)
Furthermore, at Upolu A. triostegus were found in small schools of 5 or 6 individuals, while they were commonly found in large schools of 20 to 40 individuals in other locations and in schools with up to 60 individuals at Moorea.

At Upolu, A. triostegus also demonstrated an unusual behaviour: when approached, fish retreated into holes, whereas in other locations they did not change their behaviour during our sampling and continued to swim openly in schools. Further, while sampling in most locations took our team ca. $1.5 \mathrm{~h}$ (total \# fish collected per site: $10 \mathrm{~A}$. triostegus and $5 \mathrm{Z}$. cornutus), at Upolu sampling time nearly doubled to $3 \mathrm{~h}$ and only two thirds of the number of fish were collected. We suspect that Upolu's very low coral cover and the competition for space with Acanthurus guttatus and Ctenochaetus hawaiiensis contributed to the sampling difficulties. Reduced fish sizes and behavioral observations together suggest that the habitat of the two fish species is degraded and that heavy fishing pressure exists on the coastal ecosystems around Upolu.
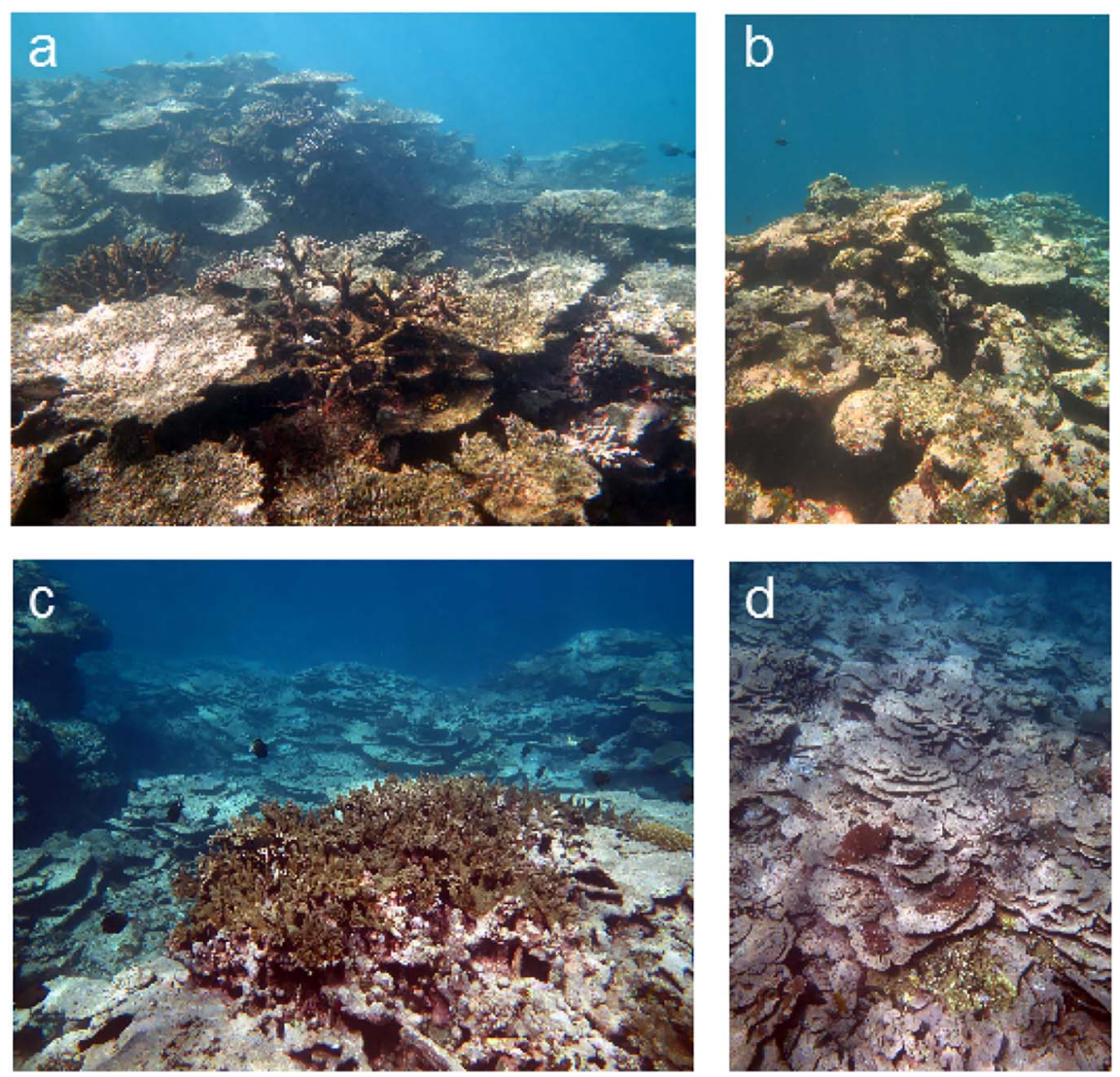

Fig. 5. Former coral reef habitat in Upolu with low coral cover and dead coral skeletons. a \& b) Dead coral skeletons still standing and overgrown by algal turf indicate relatively recent coral die-off. c \& d) In some areas with low coral cover, high cover in crustose coralline algae indicate a positive local trend and potential for recovery. All pictures taken between Nov. 29 and Dec. 03, 2016. 


\subsection{Low live coral cover in most areas}

Surveys conducted in 2006 on the reefs of American Samoa indicated a mean live coral cover between 20 and 30\% for most of the islands except for the Swains where live coral cover reached $45 \%$ (Birkeland et al., 2008; Brainard et al., 2008). In contrast, coral cover in Upolu during our surveys in 2016 was extremely low ( $<1 \%$ ) at roughly half of the sites, below $5 \%$ at more than two thirds of sites, and below $10 \%$ at more than three quarters of sites (Fig. 4). In most areas stands of recently dead and overgrown Acropora tables, dead staghorn corals and mixed dead branching and massive coral species indicated relatively recent coral die-off. Previously, many reef areas may have had very high coral cover (estimated at $60-80 \%$, Fig. 5).

In bay areas with human settlements (Cape Fatuosofia, Fagaloa Bay, Falefa), the dead coral substrate was mostly overgrown by macroalgae and the water was usually turbid. Macro algae cover in these areas was markedly higher (33-42\%), compared to fore reef locations further away from the settlements (0-3\%). This may be related to higher nutrient input into coral reefs close to rural areas, as these nutrients favor fast growth of macro algae that compete for space with slow-growing hard corals. Similarly, in American Samoa, small human population sizes in Rose and Swains islands were related to higher coral and

Table 1

Survey number and GPS coordinates of 36 sites that had $\geq 50 \%$ cover of crustose coralline algae (CCA), which may aid in recovery of coral populations.

\begin{tabular}{|c|c|c|c|}
\hline Site number & CCA cover $(\%)$ & Latitude & Longitude \\
\hline \multicolumn{4}{|l|}{ Northwest } \\
\hline 18 & 50 & $\mathrm{~S} 13^{\circ} 48.556^{\prime}$ & W172 $01.995^{\prime}$ \\
\hline 19 & 50 & $\mathrm{~S} 13^{\circ} 48.435^{\prime}$ & $\mathrm{W} 172^{\circ} 01.791^{\prime}$ \\
\hline \multicolumn{4}{|l|}{ Southwest } \\
\hline 23 & 75 & $\mathrm{~S} 13^{\circ} 51.248^{\prime}$ & $\mathrm{W} 172^{\circ} 07.679^{\prime}$ \\
\hline 24 & 65 & $\mathrm{~S} 13^{\circ} 51.503^{\prime}$ & $\mathrm{W} 172^{\circ} 07.621^{\prime}$ \\
\hline 25 & 70 & $\mathrm{~S} 13^{\circ} 51.696^{\prime}$ & W172 $07.483^{\prime}$ \\
\hline 26 & 55 & $\mathrm{~S} 13^{\circ} 51.949^{\prime}$ & W172 $07.332^{\prime}$ \\
\hline 34 & 65 & $\mathrm{~S} 13^{\circ} 53.358^{\prime}$ & $\mathrm{W} 172^{\circ} 05.940^{\prime}$ \\
\hline 37 & 60 & $\mathrm{~S} 13^{\circ} 53.860^{\prime}$ & W172 $05.498^{\prime}$ \\
\hline 39 & 50 & $\mathrm{~S} 13^{\circ} 54.430^{\prime}$ & $\mathrm{W} 172^{\circ} 04.952^{\prime}$ \\
\hline 48 & 60 & $\mathrm{~S} 13^{\circ} 54.963^{\prime}$ & W172 $02.515^{\prime}$ \\
\hline 49 & 60 & $\mathrm{~S} 13^{\circ} 55.245^{\prime}$ & $\mathrm{W} 172^{\circ} 02.154^{\prime}$ \\
\hline 56 & 50 & $\mathrm{~S} 13^{\circ} 56.289^{\prime}$ & $\mathrm{W} 172^{\circ} 00.410^{\prime}$ \\
\hline \multicolumn{4}{|c|}{ Central southwest } \\
\hline 59 & 80 & $\mathrm{~S} 13^{\circ} 56.782^{\prime}$ & $\mathrm{W} 172^{\circ} 58.524^{\prime}$ \\
\hline 60 & 60 & $\mathrm{~S} 13^{\circ} 57.254^{\prime}$ & W172 $57.967^{\prime}$ \\
\hline 63 & 80 & $\mathrm{~S} 13^{\circ} 58.809^{\prime}$ & $\mathrm{W} 172^{\circ} 57.115^{\prime}$ \\
\hline 64 & 80 & $\mathrm{~S} 13^{\circ} 58.863^{\prime}$ & W172 $57.147^{\prime}$ \\
\hline 65 & 60 & $\mathrm{~S} 13^{\circ} 59.308^{\prime}$ & $\mathrm{W} 172^{\circ} 56.408^{\prime}$ \\
\hline 66 & 50 & $\mathrm{~S} 13^{\circ} 59.867^{\prime}$ & $\mathrm{W} 172^{\circ} 55.554^{\prime}$ \\
\hline 67 & 70 & $\mathrm{~S} 14^{\circ} 00.338^{\prime}$ & $\mathrm{W} 172^{\circ} 55.223^{\prime}$ \\
\hline 68 & 70 & $\mathrm{~S} 14^{\circ} 00.556^{\prime}$ & $\mathrm{W} 172^{\circ} 54.138^{\prime}$ \\
\hline 71 & 70 & $\mathrm{~S} 14^{\circ} 01.157^{\prime}$ & $\mathrm{W} 172^{\circ} 52.683^{\prime}$ \\
\hline 72 & 55 & $\mathrm{~S} 14^{\circ} 01.880^{\prime}$ & W172 $52.288^{\prime}$ \\
\hline 73 & 50 & $\mathrm{~S} 14^{\circ} 00.826^{\prime}$ & W172 $51.788^{\prime}$ \\
\hline 74 & 50 & $\mathrm{~S} 14^{\circ} 00.538^{\prime}$ & W172 $51.687^{\prime}$ \\
\hline \multicolumn{4}{|l|}{ Central south } \\
\hline 79 & 50 & $\mathrm{~S} 14^{\circ} 00.480^{\prime}$ & W172 $50.917^{\prime}$ \\
\hline 81 & 60 & $\mathrm{~S} 14^{\circ} 01.670^{\prime}$ & $\mathrm{W} 172^{\circ} 50.541^{\prime}$ \\
\hline 82 & 60 & $\mathrm{~S} 14^{\circ} 00.961^{\prime}$ & $\mathrm{W} 172^{\circ} 50.414^{\prime}$ \\
\hline \multicolumn{4}{|l|}{ East } \\
\hline 100 & 65 & $\mathrm{~S} 14^{\circ} 03.667^{\prime}$ & $\mathrm{W} 172^{\circ} 25.821^{\prime}$ \\
\hline 101 & 60 & $\mathrm{~S} 14^{\circ} 03.903^{\prime}$ & $\mathrm{W} 172^{\circ} 25.769^{\prime}$ \\
\hline 109 & 60 & $\mathrm{~S} 14^{\circ} 02.738^{\prime}$ & $\mathrm{W} 172^{\circ} 25.619^{\prime}$ \\
\hline 110 & 50 & $\mathrm{~S} 14^{\circ} 02.525^{\prime}$ & $\mathrm{W} 172^{\circ} 25.328^{\prime}$ \\
\hline 111 & 60 & $\mathrm{~S} 14^{\circ} 02.216^{\prime}$ & $\mathrm{W} 172^{\circ} 25.192^{\prime}$ \\
\hline 113 & 60 & $\mathrm{~S} 14^{\circ} 01.110^{\prime}$ & $\mathrm{W} 172^{\circ} 24.762^{\prime}$ \\
\hline 114 & 50 & $\mathrm{~S} 14^{\circ} 01.444^{\prime}$ & $\mathrm{W} 172^{\circ} 24.827^{\prime}$ \\
\hline 116 & 60 & $\mathrm{~S} 14^{\circ} 01.558^{\prime}$ & $\mathrm{W} 172^{\circ} 25.550^{\prime}$ \\
\hline \multicolumn{4}{|l|}{ Northeast } \\
\hline 201 & 60 & $\mathrm{~S} 13^{\circ} 55.233^{\prime}$ & $\mathrm{W} 171^{\circ} 32.597^{\prime}$ \\
\hline
\end{tabular}

crustose coralline algae cover and low macro algae cover (Brainard et al., 2008).

Based on the report on the status of the coral reefs in the South West Pacific from 2007 eight sites in Samoa had a mean coral cover of $43 \%$ (range 20-66\%), but these were lagoonal inshore sites (Ah-Leong Samuelu and Sapatu, 2009). During our surveys of the fore reefs in 2016 , only 4 out of 124 sites (3\%) had a coral cover over $40 \%$. Surveys of seven more comparable fore reef locations date back to 1996, when mean hard coral cover was 32\% (range 15-68\%) (Green, 1996). We revisited three of the previously surveyed areas after 20 years and found that coral cover had drastically decreased for two of them. At Lefaga (southwest) coral cover decreased from $30 \%$ in 1996 to $1-5 \%$ in 2016, at Fagaloa (northeast) coral cover decreased from $68 \%$ to below $1 \%$ in 2016. At the third site at Saanapu (Safata Bay, central south) coral cover remained stable at $15 \%$, with higher coral cover inside Safata Bay (up to $60-80 \%$ ).

\subsection{Areas of high coral cover and areas with potential for recovery}

Two areas of high coral cover were identified, both of which lie within marine protected areas that were established in 1999 (Ah-Leong Samuelu and Sapatu, 2009). First, a turbid reef located centrally inside Safata Bay on the central south coast ( $60 \%$ coral cover). Second, the fore reef on the east coast between Lalomanu and Satitoa ( $40 \%$ coral cover), while the adjacent reefs around the smaller islands on the east coast did not show such a positive picture.

In many areas around Upolu the substrate cover of crustose coralline algae was very high ( $\geq 50 \%$ cover at $30 \%$ of sites, Table 1 ). This is even higher than the cover recorded in American Samoa, which is notable for having relatively high CCA cover. In 2006, CCA cover ranged from 20 up to $55 \%$ cover on the different islands of American Samoa (Brainard et al., 2008). CCA play an important role in reef structure and function and a high coverage in CCA is an indicator of a healthy ecosystem. Indeed, CCA are calcifiers and reef-builders contributing to the maintenance of the structural integrity of the reefs (Bak, 1976; Rasser and Riegl, 2002). In the light-flooded photic zone, competition for hard substratum is high and competitive interactions exist between crustose coralline algae and other seaweeds (Figueiredo and Steneck, 2002; Steneck, 1997). Healthy CCA can inhibit macroalgal growth and recruitment by shedding surface cells or by releasing toxic chemical compounds (McCoy and Kamenos, 2015; Vermeij et al., 2011). Furthermore, CCA play a positive role in coral recruitment acting as positive cues for coral larvae settlement and metamorphosis (RitsonWilliams et al., 2009). CCA may thus enhance coral recovery. Indeed,

Table 2

Survey number and GPS coordinates of 12 sites that had high number of coral recruits.

\begin{tabular}{lll}
\hline Site number & Latitude & Longitude \\
\hline Northwest & & \\
11 & $\mathrm{~S} 13^{\circ} 49.687^{\prime}$ & $\mathrm{W} 172^{\circ} 03.970^{\prime}$ \\
14 & $\mathrm{~S} 13^{\circ} 49.145^{\prime}$ & $\mathrm{W} 172^{\circ} 02.629^{\prime}$ \\
15 & $\mathrm{~S}^{\circ} 43^{\circ} 48.972^{\prime}$ & $\mathrm{W} 172^{\circ} 02.481^{\prime}$ \\
16 & $\mathrm{~S} 13^{\circ} 48.789^{\prime}$ & $\mathrm{W} 172^{\circ} 02.403^{\prime}$ \\
Southwest & & \\
30 & $\mathrm{~S} 13^{\circ} 52.634^{\prime}$ & $\mathrm{W} 172^{\circ} 06.669^{\prime}$ \\
Central south & & \\
73 & $\mathrm{~S} 14^{\circ} 00.826^{\prime}$ & $\mathrm{W} 172^{\circ} 51.788^{\prime}$ \\
East & & \\
104 & $\mathrm{~S} 14^{\circ} 03.835^{\prime}$ & $\mathrm{W} 172^{\circ} 24.950^{\prime}$ \\
110 & $\mathrm{~S} 14^{\circ} 02.525^{\prime}$ & $\mathrm{W} 172^{\circ} 25.328^{\prime}$ \\
114 & $\mathrm{~S} 14^{\circ} 01.444^{\prime}$ & $\mathrm{W} 172^{\circ} 24.827^{\prime}$ \\
115 & $\mathrm{~S} 14^{\circ} 01.590^{\prime}$ & $\mathrm{W} 172^{\circ} 24.863^{\prime}$ \\
Northeast & & $\mathrm{W} 171^{\circ} 31.718^{\prime}$ \\
203 & $\mathrm{~S} 13^{\circ} 55.736^{\prime}$ & $\mathrm{W} 171^{\circ} 32.692^{\prime}$ \\
206 & $\mathrm{~S} 13^{\circ} 54.829^{\prime}$ & \\
\hline
\end{tabular}


we observed many small coral recruits at some sites (Table 2), indicating a positive trend and potential for recovery at these locations (Fig. 4), although they were mostly not overlapping with areas of highest CCA cover.

\section{Conclusions}

Coral reef ecosystems of Upolu have been subjected to repeated severe disturbances, such as tropical storms, outbreaks of coral-eating starfish (COTS), and possibly coral bleaching. In addition, many local stressors further impact coastal ecosystems at Upolu. Zann (1994) summarized the main local man-made threats to Upolu's marine ecosystem as: overfishing, land reclamation (habitat loss), sedimentation, nutrient input, and pollution (toxic chemicals, rubbish, wastewater). Many of these activities seem to continue today and lead to the degradation of coastal marine ecosystems on Upolu's shores.

The previously reported global and local impacts manifested in low live coral cover and low fish biomass during our surveys along Upolu's fore reefs. Most likely the combination of different stressors led to this widespread decline of Upolu's coral reef ecosystems. In areas with standing coral reef framework and dead skeletons, the most likely causes of coral mortality were COTS outbreaks and/or coral bleaching. We further encountered areas that were almost devoid of coral colonies, indicating removal of hard substrate by storms or tsunamis. Finally, overfishing and (nutrient) pollution further hamper the recovery to a coral dominated state.

Most of the population of Independent Samoa is located on the main island of Upolu, where local human impacts are likely greater than on less inhabited islands such as Savai'i. The many local stressors at Upolu may exacerbate the negative impacts of climate change on coral reef ecosystems (Fabricius, 2005; Zaneveld et al., 2016). Reducing local impacts contributes to resilience and recovery of coastal ecosystems against global impacts. To promote resilience and recovery of coastal ecosystems at Upolu a number of local actions can be taken. These include monitoring ecosystem condition to detect impacts and recovery trends, designating (additional) marine protected areas (MPAs) \& special use zones to reduce fishing pressure, raising awareness and support local action to increase acceptance of environmental protection programs, reducing local pollution impacts, and mitigating and preventing crown-of-thorns starfish outbreaks.

In addition to local action, greenhouse gas emissions need to be reduced on a global scale immediately if coral reefs are to recover and stay healthy. In this study, we demonstrate that coral reefs even in remote locations are not immune to human impacts. These remote ecosystems may disappear before they have been observed or recorded, and a lack of study does not indicate that a reef system has not been impacted by humans.

\section{Acknowledgements}

This project has been funded through the Tara consortium, France Genomique grant number ANR-10-INBS-09, and KAUST baseline and KAUST BESE division funds to CRV. Tara Pacific consortium acknowledgement: We are keen to thank the commitment of the people and the following institutions and sponsors who made this singular expedition possible: CNRS, CSM, PSL, KAUST, Genoscope/CEA, ANRCORALGENE, France Genomique (specifically grant number ANR-10INBS-09), agnès b., the Veolia Environment Foundation, Region Bretagne, Serge Ferrari, Billerudkorsnas, AmerisourceBergen Company, Lorient Agglomération, Oceans by Disney, the Prince Albert II de Monaco Foundation, L'Oreal, Biotherm, France Collectivites, Kankyo Station, Fonds Francais pour l'Environnement Mondial (FFEM), Etienne Bourgois, UNESCO-IOC, the Tara Foundation teams and crew. Tara Pacific would not exist without the continuous support of the participating institutes. We wish to thank the Samoan government for granting sampling permission and supporting the expedition and the reviewer for comments that helped to improve this manuscript. This work is contribution number 3 of Tara Pacific.

\section{References}

Ah-Leong Samuelu, J., Sapatu, M., 2009. Samoa. In: Whippy-Morris, C. (Ed.), South-West Pacific Status of Coral Reefs Report 2007. Coral Reef Initiatives for the Pacific (CRISP), New Caledonia, pp. 84-116.

Bak, R.P.M., 1976. The growth of coral colonies and the importance of crustose coralline algae and burrowing sponges in relation with carbonate accumulation. Neth. J. Sea Res. 10, 285-337.

Bell, L.A.J., 1989. Environmental Problems in Western Samoa. Fisheries Division - Min. Apia, Apia, Samoa, pp. 16.

Birkeland, C., Craig, P., Fenner, D., Smith, L.W., Kiene, W.E., Riegl, B., 2008. Geologic setting and ecological functioning of coral reefs in American Samoa. In: Riegl, B., Dodge, R.E. (Eds.), Coral Reefs of the USA. Springer, New York, pp. 741-765.

Brainard, R., Asher, J., Gove, J., Helyer, J., Kenyon, J., Mancini, F., Miller, J., Myhre, S., Nadon, M., Rooney, J.J., Schroeder, R., Smith, E., Vargas-Angel, B., Vogt, S., Vroom, P.S., Balwani, S., Ferguson, S., Hoeke, R., Lammers, M., Lundlblad, E., Maragos, J.E., Moffitt, R., Timmers, M., Vetter, O., 2008. In: U.S. Dept. of Commerce, N.O.a.A.A., National Marine Fisheries Service (Ed.), Coral Reef Ecosystem Monitoring Report for American Samoa: 2002-2006, pp. 1-472.

Brodie, J., Fabricius, K., De'ath, G., Okaji, K., 2005. Are increased nutrient inputs responsible for more outbreaks of crown-of-thorns starfish? An appraisal of the evidence. Mar. Pollut. Bull. 51, 266-278.

Cowan, Z.-L., Pratchett, M., Messmer, V., Ling, S., 2017. Known predators of crown-ofthorns starfish (Acanthaster spp.) and their role in mitigating, if not preventing, population outbreaks. Diversity 9.

De'ath, G., Fabricius, K.E., Sweatman, H., Puotinen, M., 2012. The 27-year decline of coral cover on the Great Barrier Reef and its causes. Proc. Natl. Acad. Sci. U.S.A. 109, 17995-17999.

Fabricius, K.E., 2005. Effects of terrestrial runoff on the ecology of corals and coral reefs: review and synthesis. Mar. Pollut. Bull. 50, 125-146.

Figueiredo, M.A.d.O., Steneck, R., 2002. Floristic and ecological studies of crustose coralline algae on Brazil's Abrolhos reefs. In: Proc 9th Int Coral Reef Symp, pp. 493-497.

Government of Samoa, 2013. SAMOA Post-disaster Needs Assessment Cyclone Evan 2012. Government of Samoa, Apia, Samoa, pp. 172.

Graham, N.A.J., Wilson, S.K., Jennings, S., Polunin, N.V.C., Bijoux, J.P., Robinson, J., 2006. Dynamic fragility of oceanic coral reef ecosystems. Proc. Natl. Acad. Sci. U.S.A. 103, 8425-8429.

Green, A., 1996. Status of the Coral Reefs of the Samoan Archipelago. Department of Marine \& Wildlife Resources, American Samoa, pp. 126.

Hoegh-Guldberg, O., Mumby, P.J., Hooten, A.J., Steneck, R.S., Greenfield, P., Gomez, E., Harvell, C.D., Sale, P.F., Edwards, A.J., Caldeira, K., Knowlton, N., Eakin, C.M., Iglesias-Prieto, R., Muthiga, N., Bradbury, R.H., Dubi, A., Hatziolos, M.E., 2007. Coral reefs under rapid climate change and ocean acidification. Science 318, 1737-1742.

Hughes, T.P., Baird, A.H., Bellwood, D.R., Card, M., Connolly, S.R., Folke, C., Grosberg, R., Hoegh-Guldberg, O., Jackson, J.B.C., Kleypas, J., Lough, J.M., Marshall, P., Nystrom, M., Palumbi, S.R., Pandolfi, J.M., Rosen, B., Roughgarden, J., 2003. Climate change, human impacts, and the resilience of coral reefs. Science 301, 929-933.

Hughes, T.P., Rodrigues, M.J., Bellwood, D.R., Ceccarelli, D., Hoegh-Guldberg, O., McCook, L., Moltschaniwskyj, N., Pratchett, M.S., Steneck, R.S., Willis, B., 2007 Phase shifts, herbivory, and the resilience of coral reefs to climate change. Curr. Biol. 17, 360-365.

Hughes, T.P., Kerry, J.T., Álvarez-Noriega, M., Álvarez-Romero, J.G., Anderson, K.D. Baird, A.H., Babcock, R.C., Beger, M., Bellwood, D.R., Berkelmans, R., Bridge, T.C., Butler, I.R., Byrne, M., Cantin, N.E., Comeau, S., Connolly, S.R., Cumming, G.S., Dalton, S.J., Diaz-Pulido, G., Eakin, C.M., Figueira, W.F., Gilmour, J.P., Harrison, H.B., Heron, S.F., Hoey, A.S., Hobbs, J.-P.A., Hoogenboom, M.O., Kennedy, E.V., Kuo, C.-Y., Lough, J.M., Lowe, R.J., Liu, G., McCulloch, M.T., Malcolm, H.A., McWilliam, M.J., Pandolfi, J.M., Pears, R.J., Pratchett, M.S., Schoepf, V., Simpson, T., Skirving, W.J., Sommer, B., Torda, G., Wachenfeld, D.R., Willis, B.L., Wilson, S.K., 2017. Global warming and recurrent mass bleaching of corals. Nature 543, 373-377.

Jokiel, P.L., Rodgers, K.S., Brown, E.K., Kenyon, J.C., Aeby, G., Smith, W.R., Farrell, F., 2015. Comparison of methods used to estimate coral cover in the Hawaiian Islands. PeerJ. 3, e954.

Jones, R.J., Steven, A.L., 1997. Effects of cyanide on corals in relation to cyanide fishing on reefs. Mar. Freshw. Res. 48, 517-522.

Kwan, S., Ward, J., Satoa, M., Faitua, J., Male, F., 2016. Crown of Thorns Starfish Control Operation in Samoa 2015-2016. Marine Conservation Section, Division of Environment and Conservation, Apia, Samoa, pp. 15.

Liu, G., Strong, A.E., Skirving, W., 2003. Remote sensing of sea surface temperatures during 2002 Barrier Reef coral bleaching. In: Eos, Transactions American Geophysical Union. 84. pp. 137-141.

Liu, G., Strong, A.E., Skirving, W., Arzayus, L.F., 2005. Overview of NOAA Coral Reef Watch Program's Near-real-time Satellite Global Coral Bleaching Monitoring Activities, Proceedings of 10th International Coral Reef Symposium, Okinawa, Japan. pp. 1783-1793.

McAdoo, B.G., Ah-Leong, J.S., Bell, L., Ifopo, P., Ward, J., Lovell, E., Skelton, P., 2011. Coral reefs as buffers during the 2009 South Pacific tsunami, Upolu Island, Samoa. Earth-Sci. Rev. 107, 147-155.

McCoy, S.J., Kamenos, N.A., 2015. Coralline algae (Rhodophyta) in a changing world: integrating ecological, physiological, and geochemical responses to global change. J. Phycol. 51, 6-24. 
Morello, E.B., Plagányi, É., Babcock, R.C., Sweatman, H., Hillary, R., Punt, A.E., 2014. Model to manage and reduce crown-of-thorns starfish outbreaks. Mar. Ecol. Prog. Ser. 512, 167-183.

NOAA Coral Reef Watch, 2013. Updated daily. NOAA coral reef watch daily global 5-km Satellite virtual station time series data for southeast Florida, Mar. 12, 2013-Mar. http://coralreefwatch.noaa.gov/vs/index.php (NOAA Coral Reef Watch, College Park, Maryland, USA).

Rasser, M.W., Riegl, B., 2002. Holocene coral reef rubble and its binding agents. Coral Reefs 21, 57-72.

Ritson-Williams, R., Arnold, S., Fogarty, N., Steneck, R., Vermeij, M., Paul, V.J., 2009. New perspectives on ecological mechanisms affecting coral recruitment on reefs. Smithson. Contrib. Mar. Sci. (38), 437-457.

Steneck, R., 1997. Crustose corallines, other algal functional groups, herbivores and sediments: complex interactions along reef productivity gradients. In: Lessios, H.A., Macintyre, I.G. (Eds.), Proc. 8th Int. Coral Reef Symp, pp. 695-700.
Tiitii, U.T., 2011. Report on the Collection of Crown-of-thorns Starfish (Alamea). Fisheries division, Ministry of Agriculture and Fisheries, Apia, Samoa, pp. 8.

Vermeij, M.J.A., Dailer, M.L., Smith, C.M., 2011. Crustose coralline algae can suppress macroalgal growth and recruitment on Hawaiian coral reefs. Mar. Ecol. Prog. Ser. 422, 1-7.

Webster, P.J., Holland, G.J., Curry, J.A., Chang, H.-R., 2005. Changes in tropical cyclone number, duration, and intensity in a warming environment. Science 309, 1844-1846.

Zaneveld, J.R., Burkepile, D.E., Shantz, A.A., Pritchard, C.E., McMinds, R., Payet, J.P., Welsh, R., Correa, A.M.S., Lemoine, N.P., Rosales, S., Fuchs, C., Maynard, J.A.,

Thurber, R.V., 2016. Overfishing and nutrient pollution interact with temperature to disrupt coral reefs down to microbial scales. Nat. Commun. 7, 11833.

Zann, L.P., 1994. The status of coral reefs in South Western Pacific Islands. Mar. Pollut. Bull. 29, 52-61.

Zann, L.P., Bell, L., 1991. The effects of the Crown-of-Thorns starfish (Alamea) on Samoan reefs. In: FAO/UNDP Field Report, pp. 13. 